\title{
URINARY FLOW AND FLOW PATTERN IN PARAPLEGICS
}

\author{
By H. MADERSBACHER \\ Spinal Injury Unit of the Rehabilitation Centre Häring of the Allgemeine Unfallversiche- \\ rungsanstalt and the Department of Urology, University Hospital Innsbruck, Austria
}

Abstract. This paper deals with uroflowmetry in 34 paraplegics with neurogenic bladder dysfunction.

BASIC investigations on urinary flow in men, women, children and infants were performed by von Garrelts (1958), Backmann (1966), Girup (1970) and lately by Hartung et al. (1973) and data for normal persons were worked out. They further tried to find special flow pattern for different types of infravesical obstruction (von Garrelts, 1958; Girup, 1970). Similar data for patients with neurogenic bladder dysfunction are only seldom found in the literature and only in individual cases (Cardus et al., 1963; Claridge, 1966; Pierce et al., 1966). By theroretical and practical considerations it seemed therefore interesting to study micturition in a series of paraplegics by uroflowmetry to investigate their flow rates and to observe their flow pattern.

\section{MATERIAL AND METHODS}

In 34 paraplegics-3I men and three women-I08 micturitions, about three per patient, were measured at different times of different days according to their individual micturition habits. The paraplegics who were investigated for this study had to fulfil the following criteria:

I. No previous surgery of the bladder neck, of the prostate or at the external sphincter mechanism.

2. As uroflowmetry was carried out on a micturition chair flow-rates of only those patients who emptied the bladder normally in a sitting position were taken for investigation.

3. In order to obtain a better survey the data of only those patients were taken into account who could be classified from a urological point of view as complete or nearly complete upper motor neuron lesion (UMNL) and lower motor neuron lesion (LMNL) by urodynamic investigations and/or by the way they emptied their bladders.

Fifteen patients examined between three and nine months after the injury had had acute spinal cord lesions, whereas the other I9 patients were long-term paraplegics.

A flowmeter originally described by von Garrelts and Strandell (1972) and now produced by Elema-Schönander (EMT 434) allowing continuous recording of micturition was used. The flowmeter consists of a scale, on which the collecting basin is placed. Increasing impulses caused by the weight of the urine, filling the basin during micturition, give a signal from the attached strain gauge arrangement. This signal is amplified and connected to a derivation unit (EMT 435). The polygraph records two curves simultaneously, one being the volume-time diagram 


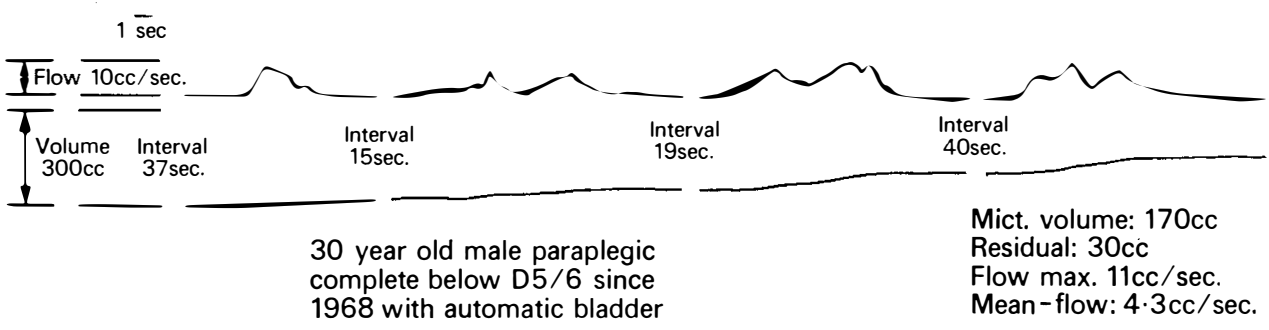

FIG. I

Flow pattern of a 30-year-old male paraplegic (since I968) with automatic bladder: typical multi-peak-flowcurve (see text).

and the other the flow rate. As regards to errors of measurement, which are negligible for the purpose of this study, one may read the original papers by von Garrelts and Strandell (1972). The scale with the basin is placed below a micturition chair, especially adapted for paraplegics.

\section{RESULTS}

Patients with automatic bladders (UMNL) were usually able to void an average of IOO-I $50 \mathrm{cc}$. mostly in three or four spurts by stimulating their individual trigger mechanism. The result is a somewhat characteristic multipeak flow curve (fig. I). The intervals between these spurts are of about I5-30 secs. duration, sometimes even longer, during which time the patients stimulate their trigger mechanisms. Once voiding starts most of them try to relax as far as possible, some assist bladderemptying by mild straining towards the end of micturition.

As it is essential for any interpretation of uroflowmetric recording to consider at least two rates, either volume and maximum flow or volume and time of micturition the diagram (fig. 2) shows the correlation between volume and maximum flow rate of 69 micturitions in 22 patients with induced bladder automatism: the dotted line marks the normal volume maximum flow regression line given by von Garrelts (1958) for volumes under $250 \mathrm{cc}$. in healthy persons, the continuous line shows the corresponding results in paraplegics: the average flow rates of $9.4 \mathrm{cc}$. $/ \mathrm{sec}$. are less than in healthy people, even when the fairly small amounts of voided urine are taken into account. The relatively small volumes are the result of bladdertraining by means of which patients are taught to empty the bladder every three to four hours, in order to avoid urinary leakage by reflex-incontinence. At the beginning, when reflex-voiding developed, the flow rates normally were lower and improved during the next months, though flow rates could vary considerably depending on the shape of the individual patients from day to day.

Patients with LMNL empty their bladder by straining and Credé, their flow curves sometimes resemble those of patients with $\mathrm{BPH}$ as described by von Garrelts (1958): the curve rises sharply to reach the peak and then falls off slowly (fig. 3). Mostly fairly short interruptions of flow sometimes occur during which the patients gain new force for straining.

The volume-maximum flow diagram of these patients show that the voided volumes are-according to their micturition schedule-between I50 and $250 \mathrm{cc}$. 


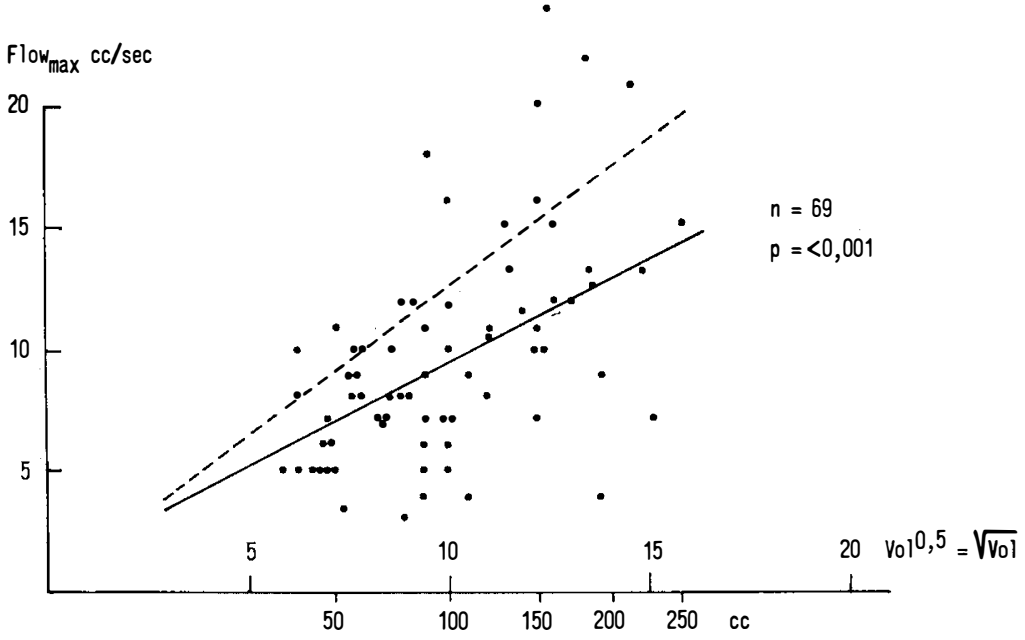

69 Micturition Recordings in 22 patients with automatic bladder

$-=\mathrm{Vol}^{0,5}-\mathrm{F}_{\max }$ regression line of paraplegics with automatic bladder

-.- = $\mathrm{Vol}^{0,5}-\mathrm{F}_{\max }$ regression line of healthy persons (age group $25-50$ ) with voided volumes below 220 cc (v.Garrelts, 1958)

FIG. 2

Sixty-nine micturition recordings of 22 patients with automatic bladder. Volume (the values are raised to the power of 0.5 ) is marked on the abscissa and the corresponding maximal flow on the ordinate. Regression line in comparison to that of healthy person according to v. Garrelts (I958).

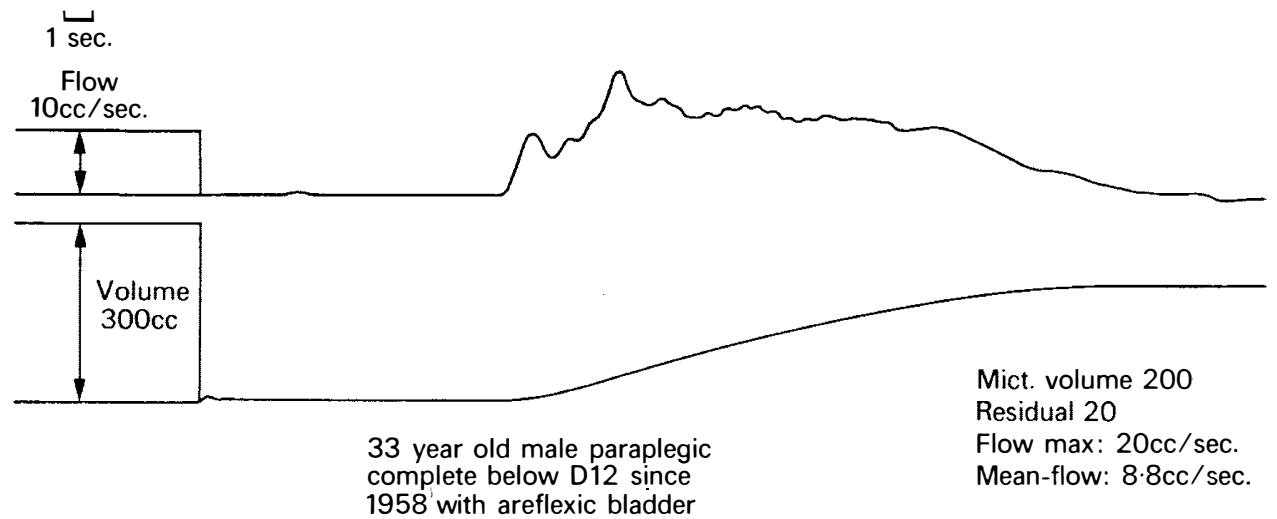

FIG. 3

Flow pattern of a 33-year-old paraplegic (since 1958) with areflexic bladder, voiding by straining and Credé (see text). 


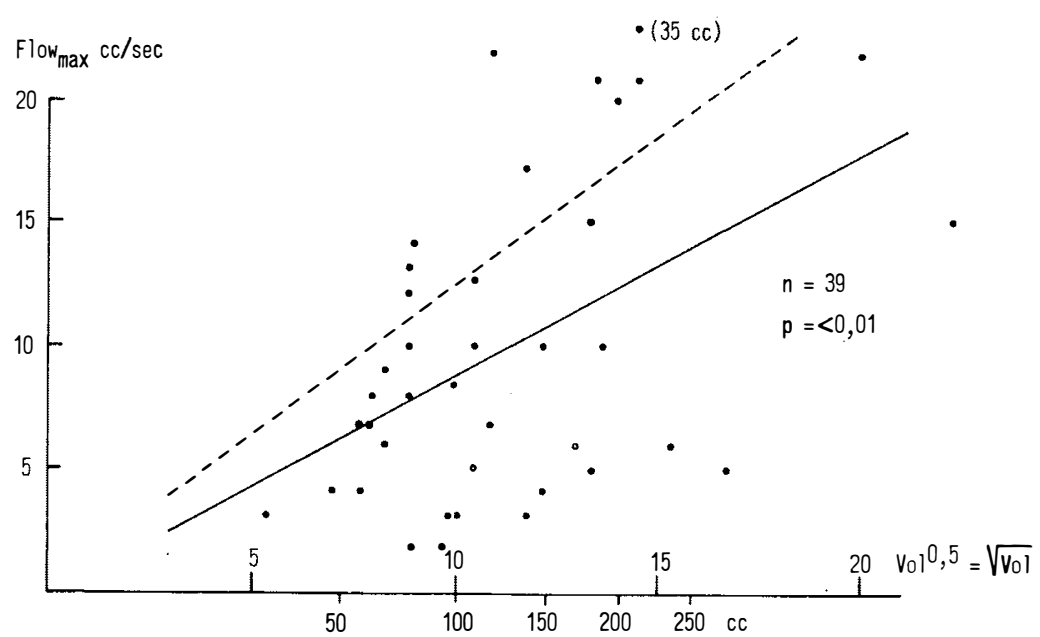

39 Micturition Recordings in 12 patients with areflexic bladder, voiding by straining and (or) Credé

$-V_{0} 1^{0,5}-F_{\max }$ regression 1 ine of paraplegics with areflexic bladder

$---=V_{01} l^{0,5}-F_{\max }$ regression line of healthy persons (age group 25-50) with voided volumes

below $220 \mathrm{cc}$ (v.Garrelts, 1958)

FIG. 4

Thirty-nine micturition recordings of $\mathrm{I} 2$ patients with areflexic bladder, voiding by straining and/or Credé. Volume (the values are raised to the power of 0.5 ) is marked on the abscissa and the corresponding maximum flow on the ordinate. Regression line in comparison to that of healthy persons according to v. Garrelts (1958).

The urinary flow rates vary between three and $35 \mathrm{cc}$./sec. depending on the force of straining and the degree of functional obstruction of the urethra at the level of the pelvic floor (fig. 4). Therefore the correlation between volume and maximum flow is less significant than in patients with automatic bladders. Altogether the maximum flow rate in this group with an average of IO.I cc./sec. is also lower than in healthy persons.

\section{DISCUSSION}

Paraplegics show according to their pathophysiology of bladder emptying characteristic flow pattern. Their urinary flow rates are diminished. The decrease is nearly similar in patients with automatic and with autonomous, areflexic bladders. As it can be demonstrated by urodynamic studies the main reason for this phenomenon in patients with automatic bladders is detrusor-sphincter-dyssynergia recognisable on increased EMG activity of the pelvic floor during micturition. $\mathrm{X}$-ray studies and sphincterometry clearly demonstrate the location of functional obstruction (Rossier \& Ott, 1973).

In patients with LMNL, who void by straining and Credé, the pelvic floor, even when paralysed, effects an obstruction of the urethra: with descent of the bladder during straining, mediated by the paretic pelvic floor, the urethra becomes 
kinked and narrow at the level of the pelvic floor, thus effecting a functional obstruction. This is sometimes the reason for poor flow. despite abnormal high intravesical pressure and good funnelling of the bladder neck in these patients.

Changes in the urodynamics, in general, were proved to interfere with the self-cleaning mechanism of the urinary tract. Decreased urinary flow and altered flow pattern can therefore be regarded as one of the factors causing recurrent bacteriuria and urinary infection in paraplegics.

\section{SUMMARY}

In 34 paraplegics with neurogenic bladder dysfunction 108 uroflowmetries were performed using the uroflowmeter described by Garrelts and Strandell.

Paraplegics show according to their pathophysiology of bladder emptying characteristic flow pattern. Their urinary flow rates are diminished. The decrease as compared with healthy people is nearly similar for patients with automatic and with autonomous areflexic bladders. Some pathophysiological aspects for these findings are discussed. One may conclude that decreased urinary flow and altered flow pattern, as changes of urodynamics in general, can be regarded as one of the factors causing recurrent bacteriuria and urinary infections in paraplegics.

\section{RÉSUME}

Chez 34 paraplégiques avec dysfonction de la vessie neurogène, I08 débitemétries ont été effectuées utilisant le débitmètre décrit par Gerrelts et Strandell. Les débits enregistrés sont diminués. La diminution du débit urinaire est comparé aux personnes avec des vessies normales et est pratiquement similaire pour les malades porteurs d'une vessie automatique ou d'une vessie autonome. Les aspects physiopathologiques des résultats sont discutés. On peut conclure que la diminution du débit urinaire avec altération du profil, ainsi que des changements urodynamiques en général, peuvent être considérés comme des facteurs favorisant une bactériurie récurrente avec infection urinaire chez les paraplégiques.

\section{ZUSAMMENFASSUNG}

Bei 34 Paraplegikern mit neurogener Dysfunktion der Blase wurden I08 Harnflußmessungen mit dem Uroflowmeter von Garrelts und Strandell ausgeführt.

Entsprechend der Pathophysiologie der Blasenentleerung zeigen Paraplegiker charakteristische Miktionsmuster. Ihre Harnflußrate ist im Vergleich zum Normalen verringert und zwar bei Patienten mit automatischer und autonomer Blase in etwa gleicher Weise.

Einige pathophysiologische Gesichtspunkte werden diskutiert. Man kann annehmen, daß der verminderte Harnfluß und das geänderte Miktionsmuster, sowie Veränderungen der Urodynamik im allgemeinen, mit eine der Ursachen für rezidivierende Bakteriurien und Harnwegsinfekte bei Paraplegikern sind.

Acknowledgement. I should like to acknowledge the help and assistance of Sister Gerti Rieger (RZ Häring) in doing this investigation.

\section{REFERENCES}

Cardus, D., Queseda, E. M. \& Scott, F. B. (1963). Studies on the dynamics of the bladder. F. Urol. 90, 425-433.

Claridge, M. (I966). Intravesical pressure and outflow resistance during micturition. Acta neurol. Scan., Suppl. 20, 42, 95-104. 
Backmann, K.-A. (1966). Micturition in Normal Women. Esselte AB, Stockholm.

v. GarRELTS, B. (1958). Quantitative Analysis of Micturition. Svenska Trycheriaktiebolagel, Stockholm.

v. GarRelts, B. \& StRANDELl, P. (1972). Continuous recording of urinary flow-rate. Scand. 7. Urol. Nephrol. 6, 224-227.

v. GaRrelts, B. \& StRANDEll, P. (1972). Apparatus for calibration of a uroflowmeter. Scand. F. Urol. Nephrol. 6, 29-3I.

GierUP, J. (1970). Micturition studies in infants and children. Scand. F. of Urology and Nephrology, Suppl. 5, Stockholm.

Hartung, R., Rogenhofer, G. \& TAMMEN, H. (I973). Erstellung von Normbereichen in der Uroflowmetrie. Urologe, Ar2, I43-I47.

PIerce et al. (197I). VA Hospital, Long Beach, cit. by E. Bors and A. E. Comarr. In Neurological Urology, p. 53. S. Karger, Basel-München-Paris-New York.

Rossier, A. B. (I97I). Probleme der neurogen gestörten Blase. Actuelle Urologie, 2, 239. 